\title{
The Perceived Value and Profile of Protected Areas Visitors: a Case study of the Guayas Province, Ecuador
}

\author{
Mauricio Carvache-FrancoA, Orly Carvache-Franco ${ }^{B}$, \\ María Magdalena Solis-RadillaC, Wilmer Carvache-Franco ${ }^{D^{*}}$ \\ Received: February 14, 2019 | Revised: June 10, 2019 | Accepted: June 12, 2019
}

DOI: $10.5937 / g p 23-20582$

\begin{abstract}
In the literature on tourism and travel, there is a large number of studies on the perceived value, however, natural protected areas and its relationship with the profile of the tourist has been little investigated. Hence, the importance of posing the main objective, to evaluate the relationship between the perceived value with the satisfaction and loyalty of the visitors of Morro Mangroves Wildlife Refuge, Santay Island National Recreation Area and Samanes National Recreation Area, three vulnerable protected areas located in the province of Guayas in Ecuador. The study was conducted in situ with 382 surveys, finding that the perceived values that are related to satisfaction and loyalty were functional value and emotional value.
\end{abstract}

Keywords: tourism; perceived value; socio-demographic profile; protected natural areas

\section{Introduction}

The rapid growth of the tourism industry in the world has given rise to new tourism trends with segments of markets rising from the new needs of demand (Aliman et al., 2014), motivated, among other factors, by the globalization of markets and increasingly informed consumers with a high sense of the environmental problems in the world which makes them more demanding when making decision on their trips (Echtner \& Ritchie, 2003; Sheham et al., 2016). These factors lead to growing competitiveness among countries, regions, cities and destinations that are forced to design and implement appropriate strategies to estab- lish a differentiation with their competitors and position themselves in their target markets, which allows them to attract new customers as well as maintain existing ones (Min-Seong et al., 2018; Sheham et al., 2016). According to Rodríguez (2012), it is the tourists who must perceive this competitive differentiation of the destination since from their perceptions they acquire a travel behavior.

On the other hand, undoubtedly one of the main attractions that trigger tourism activity are natural resources, but the incessant increase in the flows of national and international tourists each year can lead to

\footnotetext{
A Universidad Espíritu Santo-Ecuador; mauricio2714@hotmail.com

B Universidad Católica de Santiago de Guayaquil. Facultad de Especialidades Empresariales, K1.5, Av. Carlos Julio Arosemena, Guayaquil, Ecuador; orly.carvache@cu.ucsg.edu.ec

C Universidad Autónoma de Guerrero. Facultad de Turismo, Acapulco, Guerrero, México; magdalenasolis27@gmail.com

D Escuela Superior Politécnica del Litoral, ESPOL, Facultad de Ciencias Sociales y Humanísticas, Campus Gustavo Galindo Km 30.5 Vía Perimetral, P.O. Box 09-01-5863, Guayaquil, Ecuador; wcarvach@espol.edu.ec

* Corresponding author: Wilmer Carvache-Franco; e-mail: wcarvach@espol.edu.ec
} 
major changes in ecosystems (Si-Shyun, 2018). This can represent a high cost for the societies, cultures and host environments, due to the possible environmental destruction that would put their tourism heritage at risk which represents a cause of great concern for all sectors of the community (i.e., governments, professionals, local community, as well as a topic of interest to academics and researchers), who agree that in order for tourism to be maintained in a sustained manner, preventive or remedial measures should be considered to avoid a major negative impact (Briassoulis \& Van Der, 2013; Tanti \& Raya, 2016).

In this context, the destinations that base their tourist offers mainly on their natural resources face great challenges to maintain them, due to the increase in the demand of tourists who like contact with nature. They grant greater value to the spaces that are perceived as responsible in ecological terms to carry out their trips, which, at the same time produces a permanent pressure to the surroundings of the place (Thapa \& Lee, 2017). Protected natural spaces have become a "new offer" in recent decades, representing an impetus to rural community development based on tourism and a key element that allows economic diversification and important social benefits (Muñoz, 2008). Many protected areas around the world face challenges and competition in the face of the growing demand and popularity of nature-based tourism, so to provide experiences to the community and its visitors, they have to optimize the experience assuming the double mandate of providing the enjoyment through recreational activities and to maintain the sustainability of their natural areas that constitute part of the tourist heritage of the place (Thapa \& Lee, 2017; Wolf et al., 2017).

In the literature of marketing and tourism, the studies on the perceived value of tourist consumers who like contact with nature (nature-oriented, green, ecological, etc.) highlight the importance of knowing how and which of the attributes of the destination give tourists a greater value during their travel experience; considering that this market segment has an appreciation, understanding and collective assessment of the existence of environmental problems in the world (Chiu et al., 2014; Mostafa, 2007). Hence, this research focuses on analyzing the perceived value in relation to the socio-demographic profile of national and international tourists who have had a specific experience in three protected natural areas: Morro Mangrove Wildlife Refuge, Santay Island National Recreation Area and Samanes National Recreation Area, vulnerable protected areas located in the Province of Guayas in Ecuador.

The theoretical and empirical findings may have implications in the management of these sites and contribute to facilitating the knowledge of the characteristics of this market segment, made up of homogeneous groups with similar needs and that differ among themselves in some significant feature, such as nationality, gender, age, educational level. This study may also have implications on how to monitor and correctly administer the resources of these protected natural areas as a measure that guarantees the environmental quality through which a sustainable activity is achieved that continues to provide satisfactory experiences to this tourism market segment.

\section{Literature Review}

Tourism is a set of activities of the most importance in economic terms in the world, representing, for many developing countries, an opportunity to generate business that stimulates local economic activity and thus, contributes to the development of the place and improves the quality of life of its inhabitants (Aliman, et al., 2014; Hartwell et al., 2016). The natural spaces placed on the market as a rural tourism product, in the case of protected areas, provide tourist activities with many and varied attractions, as well as opportunities for unique experiences. They are offered under regulations that restriction their operation and have multiple levels of development, with the aim of preserving the environment and the ecosystems including damage and pollution to vegetation, water, wildlife, and air quality (Cheng \& Wu, 2015). This responsibility must be assumed by all those involved in tourism and society in general, contribut- ing to good practices aimed at caring for the environment with the sole purpose of preserving the tourist heritage (Buckley, 2018; Hernández et al., 2017; Thapa \& Lee, 2017).

For D'Souza et al. (2006), the environmental knowledge of nature-oriented tourism can be conceived from two orientations: the first has to do with the knowledge acquired from the influence of the individual's experience with nature. The second, the wisdom applied by individuals to contribute to reducing the negative impact on nature, that is, it can happen that even when individuals have a high level of environmental knowledge they assume negative behaviours towards nature, or conversely generate a high level of consciousness that leads them to assume a behaviour in favour of environmental care, in addition to promoting favourable attitudes toward nature (Bamberg \& Möser, 2007; Hernández et al., 2017). Other scholars consider environmental 
knowledge as one-dimensional, but that it must be segmented into two constructs based on the amount of objective (real) and subjective (perceived) knowledge, with respect to the environmental conditions of protected areas (Bamberg \& Möser, 2007). Environmental tourism responsibility refers to responsible travel, especially to some protected natural conservation areas (Wolf et al., 2017).

\section{Sociodemographic Profile of the Tourist Visiting Protected Natural Areas}

The evolution in the lifestyles of travelers gives rise to the emergence of new needs, behaviors, and modalities of tourism as it involves tourists who are usually more informed and aware of what they want from their trips. This is the case for tourists who like contact with nature and, among other characteristics, tend to be more sensitive to the environment, show respect for the culture of host destinations and seek to experiment and learn from the place (Chiu et al., 2014; Raj, 2007). The protected natural areas, where the main attraction is natural resources (as well as a set of attributes, products, services, access facilities, etc.) which are transformed into opportunities to enjoy them, represent opportunities for this market segment achieve great experiences from the visit. That is to say, the protected natural areas have important degrees of attraction for the visitor, but it is necessary for destinations that include protected natural areas in their tourism offer to effectively manage their resources, in order to provide a response to the needs of this tourist segment. Therefore, it is necessary to know the sociodemographic characteristics to determine the tastes, preferences and travel habits of tourists which is crucial information in the planning and innovation of these protected areas as tourist products (Raj, 2007).

The relationship between the profile of tourists and the way in which they give value to the experience in protected areas will depend to a large extent on the functional, affective and social benefits received. According to the marketing literature, they are described as the main reason for traveling (tangible attributes) which trigger the affects (emotions) that in turn are related to the intangible attributes of the experience (Pawitra \& Tan, 2003). Thus, all the elements that participate in the configuration of positive experiences for a tourist's influence cognition and affect, contribute to the increase in value. This means that when the factors that provide the tourist with a satisfactory person-environment interaction are combined, the value in the experience is increased (Fiore \& Kim, 2007). Likewise, some scholars recognize social interaction as an important dimension of the quality of experience and a determining factor of perceived val- ue, since it can significantly affect the dimensions of value during the intercultural exchange between local people and tourists. By participating in knowledge development, tourists learn something different from what they are exposed to in their usual environment (Chiu et al., 2014; Rasoolimanesh et al., 2016; Zhang et al., 2017).

As previously mentioned, the perceived value involves the functional, affective and social dimensions, from which the general evaluation of the experience lived by the tourists is derived, and which, in turn, consists of the perception of the balance between the benefits obtained and the costs assumed (Bajs, 2015; Solís-Radilla et al., 2016; Zeithaml, 1988). Resulting from this interaction are the main components that contribute to the attitudes and behaviors of tourists towards the product or service (Rasoolimanesh et al., 2016). Therefore, we cannot lose sight of the fact that the decision of the consumer could be strongly influenced by sociodemographic characteristics, and therefore, allows tourist destinations to be aware of the criteria that creates the segmentation of their clients, which is an important tool that will allow them to distinguish the tastes and preferences of their visitors, use tourism resources adequately towards each segment and achieve sustainable tourism development (Erragcha \& Romdhane, 2014; Guijarro et al., 2014; Lee et al., 2016).

\section{Perceived Value of Protected Natural Areas}

In recent decades, the demand and popularity of nature-based tourism has led to various forms of tourism (e.g., ecotourism, green tourism, nature tourism, etc.) which stand out from many other forms of tourism by being associated with recreational activities that contribute to a healthier life, challenging several sites to maintain the sustainability of resources, as well as optimize the experience, grant value and satisfy its visitors (Thapa \& Lee, 2017).

In marketing literature, the concept of perceived value has been widely used to analyze and understand the future behavior of tourists in relation to purchasing decisions (Jamal \& Sharifuddin, 2015). It has been considered a predictor of travelers' intentions (Eid \& El-Gohary, 2015), representing a good base for destinations to attract tourists who share common needs and values, offering practical implications for the commercialization of ecotourism experiences (Kim \& Park, 2017). Therefore, tourist destinations must increase their capacity to attract new tourists, without neglecting the promotion and conservation of lasting relationships with tourists who have already visited it (Bala et al., 2014), since future behavior assumed by the consumer is the result of the perceived value of each tourist experience (Chiu et al., 2014). 
From this approach, perceived value is recognized as a multidimensional concept which involves individual evaluations on the benefits obtained from the travel experience in comparison with the sacrifices made and which are conditioned by aspects of a rational, affective and social nature (Chiu et al., 2014). That is to say, the perceived value is subject to the judgments of the tourist, whose evaluation of the obtained results involves the information prior to the purchase, the quality of the services, the tourist resources, the surrounding nature, as well as the time, money and effort invested, among other aspects (Jamal \& Sharifuddin, 2015). In summary, the perception of value in a tourist experience is defined as the general assessment made by consumers with respect to the utility of a product, based on their own perceptions of what they receive and what is provided (Zeithaml, 1988). These conceptions of value are based largely on a utilitarian perspective that involves economic (cognitive) and affective (emotional) evaluations, that is, between costs and benefits measured after the experience (Oliver, 1997, p. 394; Sánchez-Fernández \& Iniesta-Bonillo, 2007). This utilitarian definition of perceived value is widely accepted among scholars of value in the context of tourism services (Chen \& Chen, 2010; Gallarza \& Gil, 2008; Si-Shyun, 2018).

In the context of tourism, the study of perceived value covers all types of tourism products, since according to Gallarza \& Gil (2008), the value does not lie in the product purchased or in the brand chosen, but in the experience derived from consumption. Some findings in studies have revealed that perceived value exerts a positive and significant effect on the satisfaction of experience (Chen \& Tsai, 2007; Prayag et al., 2013; Sun et al., 2013), directly influencing the fidelity of the experience (Chen \& Tsai, 2010; Oliver, 1997).

Ecotourism, green tourism or nature-oriented tourism is a segment that is constantly developing, reaching a growing popularity around the world, causing each tourist destination to receive more and more tourists who like contact with nature and are willing to assume the commitment to comply with the rules of pro- tection of the natural area where they have chosen to carry out leisure activities (Cheng \& Wu, 2015; Puhak$\mathrm{ka}, 2011)$. Therefore, the value perceived by the tourists that make up this market segment will depend on the results of the experiences in the area, and if the encounter with the service is perceived positively, the value of the experience is increased by achieving satisfied customers (Fiore \& Kim, 2007). Researchers such as Baker et al. (2002) and Minor et al. (2004), agree that the encounter with the service is the antecedent of the value of the experience and the satisfaction of the tourist, arguing that both the performance of those who provide the service and the sociodemographic characteristics of the tourist's influence cognition affects the response of future behavior. Lee et al. (2007) divided perceived value into functional value, overall value, and emotional value, and tested their effects on tourist satisfaction with the demilitarized zone (DMZ) tour in South Korea. They found that all three values positively influenced tourist satisfaction. In another study, Lee et al. (2010) considered functional and emotional value in investigating festival visitors' behaviors. Their findings suggested that both types of perceived value are positively related to tourist satisfaction. Peña et al. (2012) examined the relationships between perceived value, satisfaction, and loyalty to rural tourism in Spain. Their results revealed that perceived value has a positive effect on tourist satisfaction and loyalty. Kim and Park (2017) identified four dimensions of perceived value from 14 variables: economic, functional, emotional and social. Through structural equation modeling, the functional, social, and emotional value was found to have positive effects on overall value. Further, the overall value and tourist satisfaction were a significant antecedent of destination loyalty.

Due to the above, the following hypotheses are proposed:

$\mathrm{H}_{1}$ : The perceived value has a significant and positive effect on overall satisfaction.

$\mathrm{H}_{2}$ : The perceived value has a significant and positive effect on the intentions of returning to the destination.

\section{Geographical Description of the Study Area}

Ecuador is located in the northwest of South America. It borders the Pacific Ocean to the west, Colombia to the north, Peru to the east and the Galapagos Islands to the south, which is also part of the country. It has an area of $257,217.07 \mathrm{~km}^{2}$, the official language is Spanish, and it has a population of more than 16 million inhabitants. In 1978, Quito, its capital was declared a World Heritage Site by UNESCO, due to its architectural and cultural richness, in addition to the fact that Ecuador is considered to have the most biodiversity in the world. It is second in the world in a variety of endemic vertebrates per unit of territory, third in the diversity of amphibians and fourth in the diversity of birds. Approximately $18 \%$ of its territory is a protected area in order to guarantee and conserve its natural wealth in these areas (Cuesta et al., 2017).

The landscape and cultural diversity of Ecuador represents an extraordinary opportunity for the development of tourism in its many forms, including tourism in rural areas as the territories that house a 
large number of natural and cultural attractions that are being used in the diversification of the country's tourism product, including the following natural attractions, are linked to conservation and protection areas within the National System of Protected Areas (Carvache-Franco et al., 2019; Yánez, 2016).

Morro Mangroves Wildlife Refuge: It is located in the province of Guayas, north of the Gulf of Guayaquil, very close to Puná Island, where the El Morro channel or stream begins. It has an area of 10,030 hectares and in 2010 was declared as an area protected by the existence of a large population of dolphins that inhabit Morro channel and the frigate colony of Manglecito Island. (Figure 1).

Santay Island National Recreation Area: It is located between the cities of Guayaquil and Duran, 800 meters away from the city of Guayaquil, in the middle of the great Guayas River, surrounded by mangrove trees. It has an area of 2,215 hectares, with a large plain that is flooded in the winter generating wetland that is used by waterfowl as a place of rest, shelter and nesting. In 2010, it was declared a protected area. (Figure 2).
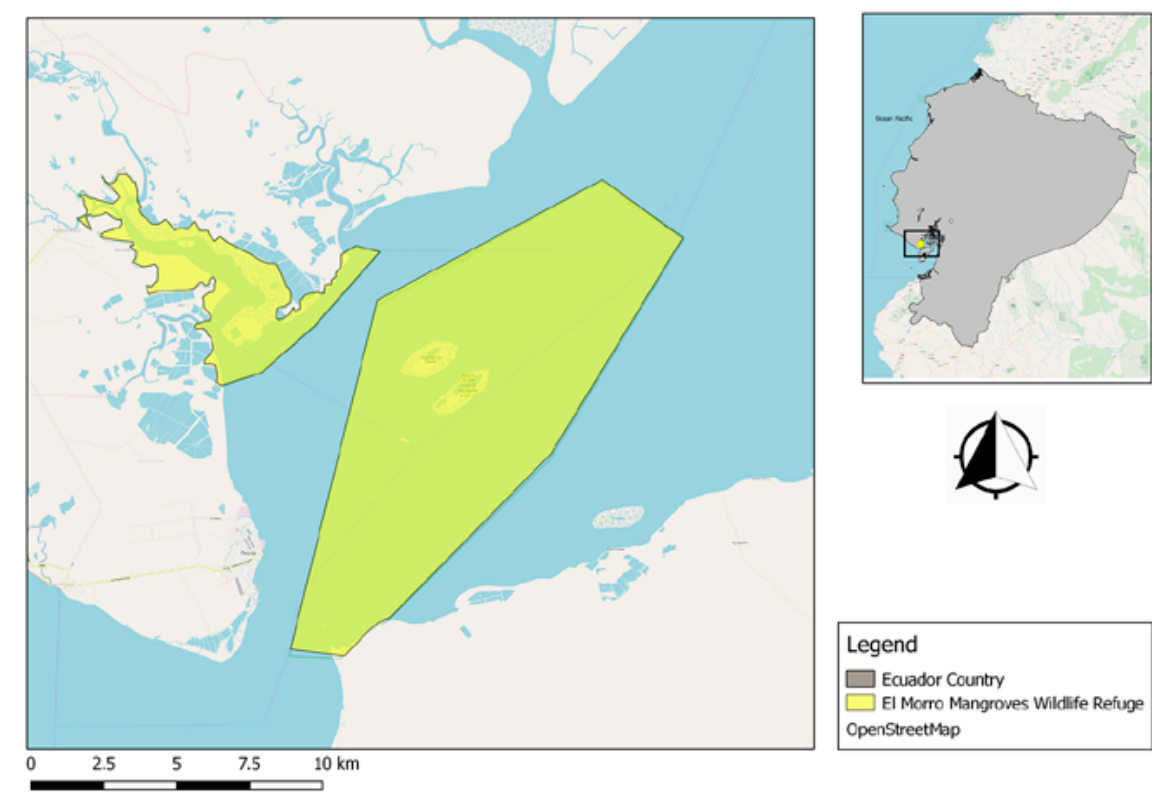

Figure 1. Morro Mangroves Wildlife Refuge (Guayas-Ecuador) Source: Prepared by the authors
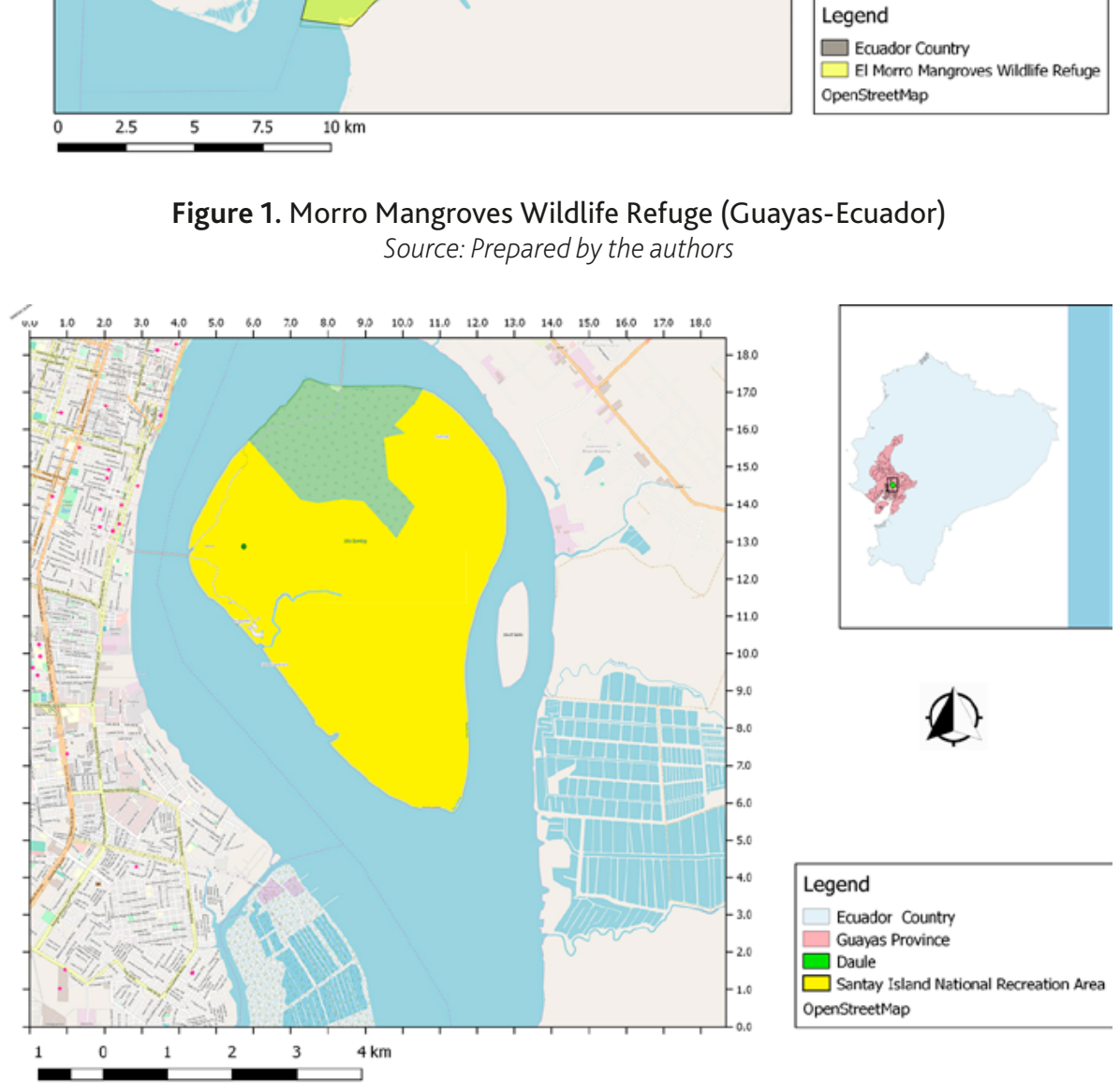

OpenStreetMap

Figure 2. Location of Santay Island National Recreation Area (Guayas-Ecuador) Source: Prepared by the authors 

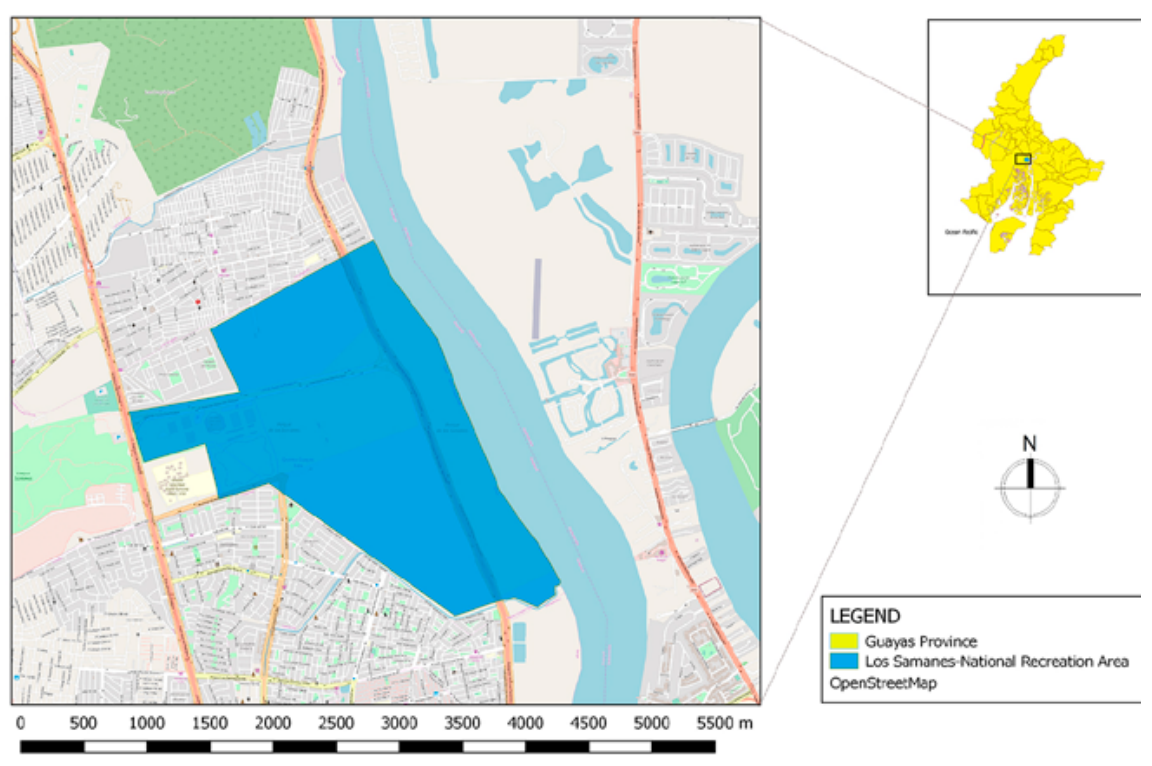

Figure 3. Location of Samanes National Recreation Area (Guayas-Ecuador) Source: Prepared by the authors

Samanes National Recreation Area: It is located in the northern area of Guayaquil, covers a land area of 380 hectares and within its urban perimeter has 2.4 kilometers of riverfront facing the banks of the Daule River, which is used for recreational and tourist purposes. In 2010, it was declared a protected area with the aim of recovering the native vegetation and wildlife that existed in this area. (Figure 3).

\section{Methodology}

\section{Instrument}

The questionnaire was constructed based on different previous studies on sociodemographic aspects, perceived value and satisfaction related to this topic (Chen \& Tsai, 2007; Chen \& Tsai, 2010; Kim \& Park, 2017; Peña et al., 2012; Prayag et al., 2013; Sun et al., 2013). The survey was organized into three sections: the first section dealt with visitor's socio-demographic information, while the second section focused on the perceived value of visitors and finally, the third section focused on satisfaction and loyalty of the visitors. For the present study, questions were used with a variety of techniques such as closed questions, multiple choice and Likert scale, which were designed to obtain sufficiently reliable results. To analyze the effectiveness of the questionnaire, a pilot test was carried out for one day at the destination, reaching 10 surveys in order to validate the tool.
The diversity of resources in rural areas that have great natural attractions and great scenic beauty, governed by conservation and protection policies within the National System of Protected Areas, represent for Ecuador an extraordinary opportunity for the development of tourist activity that contributes to the generation of jobs and benefits their communities. In Ecuador, tourism in rural areas directly generates 12,171 jobs, covered equally by women and men. (Cuesta et al., 2017; Ministry of Environment, 2015).

\section{Procedure}

The present empirical research was conducted in the three protected areas of the province of Guayas in Ecuador: "Santay Island National Recreation Area", "Morro Mangroves Wildlife Refuge" and "Samanes National Recreation Area". The collection of the sample was carried out from January to July 2018. The survey was aimed at people over 18 years old, who were members of the population under study. The information was collected in the eating and resting areas of each protected area. The tourists filled out the surveys independently, for which the interviewers were ready to answer any questions. The interviewers were students of the ESPOL University of Guayaquil, who were trained by the authors of this article to obtain the sample in the field work. 


\section{Sample}

A sample size of 382 valid surveys was obtained with a margin of error of $+/-5 \%$, a confidence level of $95 \%$ and a variance of $50 \%$ (see Table 1 ). In this investiga- tion, the data collected were analyzed and tabulated using the SPSS Version 22 program. Statistical tools such as univariate and bivariate tools were used to obtain valid results.

Table 1. Technical data of the sample

\begin{tabular}{|l|l|}
\hline Population & National and foreign visitors \\
\hline Geographic area & $\begin{array}{l}\text { Protected areas: "Santay Island National Recreation Area", "Morro Mangroves Wildlife Refuge" and } \\
\text { "Samanes National Recreation Area". Guayas, Ecuador }\end{array}$ \\
\hline Date & From January to July 2018 \\
\hline Procedure & Simple random sampling \\
\hline Confidence level & $95 \%$ \\
\hline Margin of error & $+/-5 \%$ \\
\hline Valid surveys & 382 \\
\hline
\end{tabular}

\section{Results and Discussion}

The results of the sociodemographic variables such as origin, sex, age, level of training and professional activity are illustrated in Table 2 . The sample consisted of $90.8 \%$ national visitors and $9.2 \%$ foreign visitors. Of the total sample, $57.3 \%$ were women and $42.7 \%$ were men. Of the total number of respondents, $61.3 \%$ were in the age bracket between 20- and 29-years-old, and $19.4 \%$ were in the 30 - to the 39 -years-old bracket. Seventy-seven percent of respondents had a university education, $16.8 \%$ had secondary education and $5.8 \%$ had attained a postgraduate/ master's degree or doctorate. Regarding their professional activity, the respondents were mainly students $(59.4 \%)$, private employees (13.6\%) and entrepreneurs/ business owners (8.1\%). Regarding the characteristics of the visits, $39.8 \%$ visited these protected areas once a year, $31.7 \%$ visited them every six months and $\mathbf{1 5 . 2 \%}$ every three months. Forty-nine percent of respondents visited in the company of their family and $35.1 \%$ with friends. The groups of visits were composed mostly of three to five people $(58.1 \%)$ and less than three people (26.7\%). Regarding the daily expenditure made, $41.1 \%$ spent less than 20 dollars and $34.3 \%$ spent between 20 and 40 dollars.

The importance of the information sources consulted is illustrated in Table 3. The main sources consulted before visiting the protected areas were the Internet (4.42), friends and acquaintances (4.16), followed by official sources of tourist information (3.94). The study was based on a Likert scale of 5 points, 1 being not important and 5 very important.
As illustrated in Table 4, the variables most valued in the perceived value were: "this visit is pleasant" (4.16), "I have positive feelings" (4.11) and "this visit makes me feel happy" (4.06). The emotional dimension has the highest perceived value in relation to others. Another variable with a high score is "the service is economic" (4.02), so tourists perceive these protected areas as economic. Regarding the functional value, the most valued variable is "the service has good value for money" (3.82), revealing that tourists perceive that protected areas have an acceptable quality. In terms of social value, the variable with the highest score is "I obtain social approval from others" (3.45). Regarding the total value, the variables that have high scores are: in general, "I have made the correct decision" (4.14) and in general "the service is valuable and worthwhile" (4.14), demonstrating that protected areas are perceived with a high value. The study is based on a Likert scale of 5 points, with $1=$ little and $5=$ a lot.

As illustrated in Table 5, overall satisfaction was high (4.22), revealing that tourists were satisfied in this protected area. Likewise, the satisfaction in comparison to the expectations of tourists is high (4.11). In terms of loyalty, tourists had a high level of intention to return to these protected areas (4.30). Tourists also had high intentions to recommend these protected areas (4.34). This study was based on a Likert scale of 5 points, with $1=$ little and $5=$ a lot. 
Table 2. Sociodemographic aspects and characteristics of the visit

\begin{tabular}{|c|c|c|c|}
\hline & Categories & $\mathrm{n}$ & $\%$ \\
\hline \multirow{2}{*}{ Origin } & Nationals & 346 & $90.80 \%$ \\
\hline & Foreign & 35 & $9.20 \%$ \\
\hline \multirow{2}{*}{ Gender } & Male & 164 & $42.70 \%$ \\
\hline & Female & 220 & $57.30 \%$ \\
\hline \multirow{6}{*}{ Age } & $<20$ years old & 42 & $11.00 \%$ \\
\hline & 20-29 years old & 235 & $61.30 \%$ \\
\hline & 30-39 years old & 74 & $19.40 \%$ \\
\hline & 40-49 years old & 13 & $3.40 \%$ \\
\hline & 50-59 years old & 13 & $3.40 \%$ \\
\hline & $>59$ years old & 6 & $1.60 \%$ \\
\hline \multirow{4}{*}{$\begin{array}{l}\text { Level of } \\
\text { education }\end{array}$} & Primary & 2 & $0.50 \%$ \\
\hline & Secondary & 65 & $16.80 \%$ \\
\hline & University & 292 & $76.00 \%$ \\
\hline & $\begin{array}{l}\text { Postgraduate / } \\
\text { Master / Ph.D. }\end{array}$ & 22 & $5.80 \%$ \\
\hline \multirow{7}{*}{$\begin{array}{l}\text { Professional } \\
\text { activity }\end{array}$} & Student & 228 & $59.40 \%$ \\
\hline & $\begin{array}{l}\text { Researcher/ } \\
\text { Scientifics }\end{array}$ & 6 & $1.60 \%$ \\
\hline & Businessman & 31 & $8.10 \%$ \\
\hline & Private Employee & 52 & $13.60 \%$ \\
\hline & Public Employee & 35 & $9.20 \%$ \\
\hline & Housewife & 10 & $2.60 \%$ \\
\hline & Unemployed & 14 & $3.70 \%$ \\
\hline
\end{tabular}

\begin{tabular}{|c|c|c|c|}
\hline & Categories & $\mathrm{n}$ & $\%$ \\
\hline \multirow{3}{*}{$\begin{array}{l}\text { Professional } \\
\text { activity }\end{array}$} & Retired & 3 & $0.80 \%$ \\
\hline & Informal work & 2 & $0.50 \%$ \\
\hline & Other & 2 & $0.50 \%$ \\
\hline \multirow{5}{*}{$\begin{array}{l}\text { Frequency } \\
\text { of visit }\end{array}$} & Annually & 153 & $39.80 \%$ \\
\hline & Every 6 months & 122 & $31.70 \%$ \\
\hline & Every 3 months & 58 & $15.20 \%$ \\
\hline & Monthly & 36 & $9.40 \%$ \\
\hline & Weekly & 15 & $3.90 \%$ \\
\hline \multirow{5}{*}{$\begin{array}{l}\text { Who you } \\
\text { visit }\end{array}$} & With family & 188 & $49.00 \%$ \\
\hline & With friends & 135 & $35.10 \%$ \\
\hline & With partner & 23 & $6.00 \%$ \\
\hline & Alone & 61 & $15.80 \%$ \\
\hline & Other & 18 & $4.70 \%$ \\
\hline \multirow{3}{*}{$\begin{array}{l}\text { Groups of } \\
\text { people }\end{array}$} & $<3$ people & 103 & $26.70 \%$ \\
\hline & 3-4 people & 223 & $58.10 \%$ \\
\hline & $>6$ people & 58 & $15.20 \%$ \\
\hline \multirow{6}{*}{$\begin{array}{l}\text { Daily } \\
\text { expenditure }\end{array}$} & $<\$ 20$ & 158 & $41.10 \%$ \\
\hline & $\$ 20-\$ 40$ & 132 & $34.30 \%$ \\
\hline & $\$ 40-\$ 60$ & 56 & $14.70 \%$ \\
\hline & $\$ 60-\$ 80$ & 15 & $3.90 \%$ \\
\hline & $\$ 80-\$ 100$ & 14 & $3.70 \%$ \\
\hline & $>\$ 100$ & 9 & $2.40 \%$ \\
\hline
\end{tabular}

Table 3. Importance of information sources

\begin{tabular}{|c|c|c|c|c|}
\hline Source & $\mathrm{n}$ & Minimum & Maximum & Mean \\
\hline Internet & 382 & 1 & 5 & 4.42 \\
\hline Friends and acquaintances & 382 & 1 & 5 & 4.16 \\
\hline Destination management organizations & 382 & 1 & 5 & 3.94 \\
\hline Supplier information & 382 & 1 & 5 & 3.82 \\
\hline Advertising & 381 & 1 & 5 & 3.81 \\
\hline Tourism media & 382 & 1 & 5 & 3.55 \\
\hline Fairs & 382 & 1 & 5 & 3.49 \\
\hline Travel guides & 382 & 1 & 5 & 3.34 \\
\hline Intermediaries (travel agencies or tour operators) & 382 & 1 & 5 & 3.31 \\
\hline Documentaries & 382 & 1 & 5 & 3.21 \\
\hline Opinion leaders & 382 & 1 & 5 & 3.12 \\
\hline Films and TV series & 382 & 1 & 5 & 2.96 \\
\hline Books & 382 & 1 & 5 & 2.91 \\
\hline
\end{tabular}


Table 4. Perceived value

\begin{tabular}{|c|c|c|c|c|}
\hline Variables & $\mathrm{n}$ & Minimum & Maximum & Mean \\
\hline \multicolumn{5}{|l|}{ Economic value (ECV) } \\
\hline Service is economical (affordable) & 382 & 1 & 5 & 4.02 \\
\hline Good for the price & 382 & 1 & 5 & 3.96 \\
\hline Value for money & 382 & 1 & 5 & 3.9 \\
\hline \multicolumn{5}{|l|}{ Functional value (FV) } \\
\hline Acceptable standard of quality & 382 & 1 & 5 & 3.92 \\
\hline Well organized & 382 & 1 & 5 & 3.83 \\
\hline Convenient for me & 382 & 1 & 5 & 3.97 \\
\hline \multicolumn{5}{|l|}{ Social value (SV) } \\
\hline Gains social approval from others & 382 & 1 & 5 & 3.45 \\
\hline I feel like a special person & 382 & 1 & 5 & 3.39 \\
\hline Make a good impression on other people & 382 & 1 & 5 & 3.44 \\
\hline \multicolumn{5}{|l|}{ Emotional value (EMV) } \\
\hline Enjoyable & 382 & 1 & 5 & 4.16 \\
\hline Makes me feel happy & 382 & 1 & 5 & 4.06 \\
\hline Positive feeling & 382 & 1 & 5 & 4.11 \\
\hline \multicolumn{5}{|l|}{ Overall value (OV) } \\
\hline Right decision & 382 & 1 & 5 & 4.14 \\
\hline Valuable and worth it & 382 & 1 & 5 & 4.1 \\
\hline More than what I expected & 382 & 1 & 5 & 3.79 \\
\hline
\end{tabular}

Table 5. Satisfaction and loyalty

\begin{tabular}{|l|c|c|c|c|}
\hline Satisfaction and loyalty & $\mathrm{n}$ & Minimum & Maximum & Mean \\
\hline Satisfaction (SA) & 382 & 1 & 5 & 4.22 \\
\hline Overall satisfaction & 382 & 1 & 5 & 4.11 \\
\hline Satisfaction in comparison with expectations & 382 & 1 & 5 & 4.30 \\
\hline Loyalty (LO) & 382 & 2 & 5 & 4.34 \\
\hline I have the intention to revisit this protected area & & & 5 \\
\hline $\begin{array}{l}\text { I have the intention to recommend this protected } \\
\text { area }\end{array}$ & & & \\
\hline
\end{tabular}

\section{Relationship between the perceived value and other variables}

We analyzed the relationship between perceived value and sociodemographic variables, finding that there was no significant relationship $(\mathrm{p}<0.05)$ between sociodemographic variables and perceived value. As illustrated in Table 6, all variables had a significant and positive correlation with tourist satisfaction, confirming hypothesis $\mathrm{H}_{1}$ : The perceived value has a significant and positive effect on overall satisfaction. The variables that had a greater influence on satisfaction were: "the service is well organized" (functional value), "this visit is pleasant" (emotional value), "I have positive feelings" (emotional value) and "the service has an acceptable level of quality" (functional value). Therefore, the service should be improved in terms of organization, which is pleasant, generates positive feelings and offers quality. Regarding the total value, there was a significant and positive correlation between the perceived value and satisfaction (similar results are found in Chen \& Tsai, 2007; Kim \& Park, 2017; Peña et al., 2012; Prayag et al., 2013; Sun et al., 2013).

As illustrated in Table 7, all the variables had a significant and positive correlation with the intention of returning to the destination, confirming hypothesis $\mathrm{H} 2$ : The perceived value has a significant and positive effect on the intentions of returning to the destination.

The variables that had a greater influence on the intentions of returning to the destination were: "this visit is pleasant" (emotional value), "the service is well organized" (functional value), "the service has an acceptable level of quality" (functional value), "I have positive feelings" (emotional value) and "the service is convenient for me" (functional value). Therefore, 
Table 6. Relationship between general satisfaction and perceived value (Spearman correlation)

\begin{tabular}{|c|c|c|}
\hline Variables & Correlation & Sig. \\
\hline \multicolumn{3}{|l|}{ Economic value (ECV) } \\
\hline Service is economical & 0.421 & 0.000 \\
\hline Good for the price & 0.441 & 0.000 \\
\hline Value for money & 0.450 & 0.000 \\
\hline \multicolumn{3}{|l|}{ Functional value (FV) } \\
\hline $\begin{array}{l}\text { Acceptable standard of } \\
\text { quality }\end{array}$ & 0.457 & 0.000 \\
\hline Well organized & 0.492 & 0.000 \\
\hline Convenient for me & 0.449 & 0.000 \\
\hline \multicolumn{3}{|l|}{ Social value (SV) } \\
\hline $\begin{array}{l}\text { Gains social approval from } \\
\text { others }\end{array}$ & 0.388 & 0.000 \\
\hline I feel like a special person & 0.387 & 0.000 \\
\hline $\begin{array}{l}\text { Make a good impression on } \\
\text { other people }\end{array}$ & 0.400 & 0.000 \\
\hline \multicolumn{3}{|l|}{ Emotional value (EMV) } \\
\hline Enjoyable & 0.471 & 0.000 \\
\hline Makes me feel happy & 0.451 & 0.000 \\
\hline Positive feeling & 0.460 & 0.000 \\
\hline \multicolumn{3}{|l|}{ Overall value (OV) } \\
\hline Right decision & 0.506 & 0.000 \\
\hline Valuable and worth it & 0.549 & 0.000 \\
\hline More than what I expected & 0.572 & 0.000 \\
\hline
\end{tabular}

the service should improve in terms of the pleasant, the organization, which offers quality, that generates positive feelings and that is convenient for the tourist. Regarding the total value, there was a significant and
Table 7. Relationship between the intentions to return and the perceived value (Spearman correlation)

\begin{tabular}{|c|c|c|}
\hline Variables & Correlation & Sig. \\
\hline \multicolumn{3}{|l|}{ Economic value (ECV) } \\
\hline Service is economical & 0.374 & 0.000 \\
\hline Good for the price & 0.381 & 0.000 \\
\hline Value for money & 0.407 & 0.000 \\
\hline \multicolumn{3}{|l|}{ Functional value (FV) } \\
\hline $\begin{array}{l}\text { Acceptable standard of } \\
\text { quality }\end{array}$ & 0.436 & 0.000 \\
\hline Well organized & 0.439 & 0.000 \\
\hline Convenient for me & 0.418 & 0.000 \\
\hline \multicolumn{3}{|l|}{ Social value (SV) } \\
\hline $\begin{array}{l}\text { Gains social approval from } \\
\text { others }\end{array}$ & 0.333 & 0.000 \\
\hline I feel like a special person & 0.360 & 0.000 \\
\hline $\begin{array}{l}\text { Make a good impression on } \\
\text { other people }\end{array}$ & 0.346 & 0.000 \\
\hline \multicolumn{3}{|l|}{ Emotional value (EMV) } \\
\hline Enjoyable & 0.459 & 0.000 \\
\hline Makes me feel happy & 0.388 & 0.000 \\
\hline Positive feeling & 0.418 & 0.000 \\
\hline \multicolumn{3}{|l|}{ Overall value (OV) } \\
\hline Right decision & 0.427 & 0.000 \\
\hline Valuable and worth it & 0.457 & 0.000 \\
\hline More than what I expected & 0.440 & 0.000 \\
\hline
\end{tabular}

positive correlation between the perceived value and the intentions of returning to the destination (similar results are found in Chen \& Tsai, 2010; Kim \& Park, 2017; Oliver, 1997; Peña et al., 2012).

\section{Conclusions}

The variables most valued in the perceived value were: "this visit is pleasant", "I have positive feelings" and "this visit makes me feel happy". All these variables belong to the emotional dimension, so the emotional dimension has the highest perceived value in relation to others. Another variable with a high score is "the service is economic". The total value has high scores so that protected areas are perceived as having a high total value.

In terms of satisfaction and intention to return and recommend, the overall satisfaction is high. Likewise, satisfaction compared to expectations is high. Tourists are satisfied with the experience in these protected areas. As for the loyalty of tourists, the intentions of returning and recommending are high.

Regarding the relationship of satisfaction with perceived value, this has a significant and positive effect on general satisfaction, similar results were found in (Chen \& Tsai, 2007; Peña et al., 2012; Prayag et al., 2013; Sun et al., 2013). The variables that have a greater influence on satisfaction were: "the service is well organized", "this visit is pleasant", "I have positive feelings" and "the service has an acceptable level of quality". Therefore, the service should be improved in terms of organization, which is pleasant, generates positive feelings and offers quality (similar results are found in Chen \& Tsai, 2007; Kim \& Park, 2017; Peña et al., 2012; Prayag et al., 2013; Sun et al., 2013).

Regarding the relationship of the intentions to return and the perceived value, this has a significant and positive effect on the intentions of returning to the destination, similar results were found in (Peña et al., 2012; Eid \& El-Gohary, 2015; Kim and Park, 2017). The variables that have a greater influence on the intentions of returning to the destination were: "this visit is 
pleasant", "the service is well organized", "the service has an acceptable level of quality", "I have positive feelings" and "the service is convenient for me". So it should improve the service in terms of the pleasant. The organization which offers quality, that generates positive feelings and that is convenient for the tourist. Similar results are found in (Chen \& Tsai, 2010; Kim \& Park, 2017; Oliver, 1997; Peña et al., 2012). According to the characteristics and importance of the protected areas, the type of tourist that visits these areas and the subject of perceived value, the findings of this study can be generalized to other important destinations in ecotourism.

As for theoretical implications, empirical evidence has revealed that perceived value is directly related to satisfaction and loyalty (similar results are found in Chen \& Tsai, 2007; Chen \& Tsai, 2010; Kim \& Park, 2017; Oliver, 1997; Peña et al., 2012; Prayag et al., 2013; Sun et al., 2013). The dimensions of value perceived in a protected area are economic value, functional value, social value, emotional value, and total value. The findings reveal that the main values that have to do with satisfaction and loyalty were functional val- ue and emotional value. In the study by Kim \& Park (2017) they found that functional, social and emotional values have positive effects on the general value, so similar results have been found. The main contribution of the present study to the theory is that the main values that have to do with general satisfaction and loyalty are functional value and emotional value.

As for practical implications, the results will serve the public institutions that administer the protected areas to elaborate on plans and programs according to the profile of the visitor found and at the level of perceived values found. The scientific community will benefit from information on the value perceived in ecotourism and its relationship with other variables such as satisfaction and intention to return to the destination, which will contribute to the scientific debate in this area which is little discussed in the literature. Finally, the main limitation of the present study was the temporality to take the sample because the demand may vary. It would be important to analyze the variables related to ecotourism preferences in these protected areas as a future line of research in order to create products according to demand.

\section{References}

Aliman, N. K., Hashim, S. M., Wahid, S. D. M., \& Harudin, S. (2014). Tourist expectation, perceived quality and destination image: Effects on perceived value and satisfaction of tourists visiting Langkawi Island, Malaysia. Asian Journal of Business and Management., 2(3), 212-222. http://citeseerx.ist.psu. edu/viewdoc/download?doi=10.1.1.878.2878\&rep $=$ r ep1\&type $=$ pdf

Bajs, I. (2015). Tourist perceived value, relationship to satisfaction, and behavioral intentions: the example of the Croatian tourist destination Dubrovnik. Journal of Travel Research, 54(1), 122-134. https://doi. org/10.1177/0047287513513158

Baker, J., Parasuraman, A., Grewal, D., and Voss, G. B. (2002). The influence of multiple store environment cues on perceived merchandise value and patronage intentions. Journal of marketing, 66(2), 120-141. https://doi.org/10.1509/jmkg.66.2.120.18470.

Bala, B. M., Nizam, I. H., Dalil, M., \& Kawu, A. (2014). Moderating role of affective destination image on the relationship between tourist's satisfaction and behavioral intention: Evidence from Obudu Mountain Resort. Journal of Environment and Earth Science. 4(4), 47-60. https://www.iiste.org/Journals/index.php/JEES/article/view/11191/11493

Bamberg, S., \& Möser, G. (2007). Twenty years after Hines, Hungerford, and Tomera: A new metaanalysis of psycho-social determinants of pro-en- vironmental behavior. Journal of Environmental. Psychology, 27(1), 14-25. https://doi.org/10.1016/j.jenvp.2006.12.002.

Briassoulis, H., \& Van Der S., J. (2013). Tourism and the environment: regional, economic, cultural and policy (2nd Ed.). New York, NY: Springer Science \& Business Media.

Buckley, R. (2018). Tourism and natural World Heritage: A complicated relationship. Journal of Travel Research, 57(5) 563-578. https://doi. org/10.1177/0047287517713723.

Carvache-Franco, W., Carvache-Franco, M., Carvache-Franco, O., \& Hernández-Lara, A. B. (2019). Segmentation of foreign tourist demand in a coastal marine destination: The case of Montañita, Ecuador. Ocean and Coastal Management 167, 236-244. https://doi.org/10.1016/j.ocecoaman.2018.10.035.

Chen, C. F., \& Chen, F. S. (2010). Experience quality, perceived value, satisfaction and behavioral intentions for heritage tourists. Tourism Management, 31(1), 29-35. https://doi.org/10.1016/j. tourman.2009.02.008.

Chen, C. F., \& Tsai, D. (2007). ¿How destination image and evaluative factors affect behavioral intentions? Tourism Management, 28, 1115-1122. https:// doi.org/10.1016/j.tourman.2006.07.007.

Cheng, T. M., \& Wu, H. C. (2015). How do environmental knowledge, environmental sensitivity, and 
place attachment affect environmentally responsible behavior? An integrated approach for sustainable island tourism. Journal of Sustainable Tourism, 23(4), 557-576. https://doi.org/10.1080/09669582.201 4.965177 .

Chiu, Y. T. H., Lee, W. I., \& Chen, T. H. (2014). Environmentally responsible behavior in ecotourism: Exploring the role of destination image and value perception. Asia Pacific Journal of Tourism Research, 19(8), 876-889. https://doi.org/10.1080/10941 665.2013.818048.

Cuesta, M. R., Villagómez, O. M. y Sili, M. (2017). Atlas Rural del Ecuador. Instituto Geográfico Militar del Ecuador, Ecuador: Primera Edición.

D’Souza, C., Taghian, M., \& Lamb, P. (2006). An empirical study on the influence of environmental labels on consumers. An International Journal, 11(2),162173. https://doi.org/10.1108/13563280610661697.

Echtner, C. M., \& Ritchie, J. R. (2003). The Meaning and Measurement of Destination Image. The Journal of Tourism Studies, 14(1), 37-48.

Eid, R., \& El-Gohary, H. (2015). The role of Islamic religiosity on the relationship between perceived value and tourist satisfaction. Tourism Management, 46, 477-488. https://doi.org/10.1016/j.tourman.2014.08.003.

Erragcha, N., \& Romdhaner, R. (2014). New Faces of Marketing In The Era of The Web: From Marketing 1.0 To Marketing 3.o. Journal of Research in Marketing, 2(2), 137-142. https://doi.org/doi:10.17722/jorm. v2i2.46.

Fiore, A. M., \& Kim, J. (2007). An integrative framework capturing experiential and utilitarian shopping experience. International Journal of Retail and Distribution Management, 35(6), 421-442. https:// doi.org/10.1108/09590550710750313.

Gallarza, M. G., \& Gil, I. (2008). The concept of value and its dimensions: A tool for analyzing tourism experiences. Tourism Review, 63(3), 4-20. https://doi.org/10.1108/16605370810901553.

Guijarro, G. M., Roger, M. V., \& Martí, S. M. (2014). El valor percibido de los clientes de las agencias de viajes con canal múltiple: Un análisis clúster. Papers de Turisme, 56, 61-80.

Hartwell, H., Wyatt, A., Page. S. W., Ladkin, A., \& Hemingway, A. (2016). Progress in tourism and destination wellbeing research, Current Issues in Tourism, 21(16), 1830-1892. https://doi.org/10.1080/1 3683500.2016.1223609

Hernández, L. J. Á., González M. A., Hernández, T. S., \& Ramón, O. A. A. (2017). The Impact of mass tourism in the Canary Islands in the context of world biosphere reserves. Cuadernos de Turismo, 40, 685688. https://doi.org/10.6018/turismo.40.309751.
Jamal, A., \& Sharifuddin, J. (2015). Perceived value and perceived usefulness of halal labeling: The role of religion and culture. Journal of Business Research, 68(5), 933-941. https://doi.org/10.1016/j.jbusres.2014.09.020.

Kim, K. H., \& Park, D. B. (2017). Relationships among perceived value, satisfaction, and loyalty: Community-based ecotourism in Korea. Journal of Travel \& Tourism Marketing, 34(2), 171-191. https://doi.org/10 $.1080 / 10548408.2016 .1156609$

Lee, C.-K., Yoon, Y.-S., \& Lee, S.-K. (2007). Investigating the relationships among perceived value, satisfaction, and recommendations: The case of the Korean DMZ. Tourism Management, 28(1), 204-214. https://doi:10.1016/j. tourman.2005.12.017

Lee, J. S., Lee, C. K., \& Choi, Y. J. (2010). Examining the role of emotional and functional values in festival evaluation. Journal of Travel Research, 50(6), 658696. https://doi.org/10.1177\%2Foo 47287510385465

Lee, S., Phau, I., Hughes, M., Li, Y. F., \& Quintal, V. (2016). Heritage Tourism in Singapore Chinatown: A Perceived Value Approach to Authenticity and Satisfaction. Journal of Travel \& Tourism Marketing, 33(7), 1-18. https://doi.org/10.1080/10548408.201 5.1075459 .

Ministry of Environment (2015). National System of Protected Areas of Ecuador. Available at: http://areasprotegidas.ambiente.gob.ec/es/areas-protegidas/ refugio-de-vida-silvestre-manglares-el-morro.

Minor, M. S., Wagner, T., Brewerton, F. J., \& Hausman, A. (2004). Rock on! An elementary model of customer satisfaction with musical performances. Journal of Services Marketing, 18(1), 7-18. https://doi. org/10.1108/08876040410520672.

Min-Seong, K., Jinwon, K., \& Brijesh, T., (2018). Influence of environmental knowledge on effect, nature affiliation and pro-environmental behaviors among tourists. Sustainability, MDPI, Open Access Journal, 10(9), https://doi.org/10.339o/su10093109.

Mostafa, M. M. (2007). A hierarchical analysis of the green consciousness of the Egyptian consumer. Psychology \& Marketing, 24(5), 445-473. https://doi. org/10.1002/mar.20168.

Muñoz, F. J.C. (2008). El turismo en los espacios naturales protegidos españoles, algo más que una moda reciente. Boletín de la Asociación de Geógrafos Españoles, 46, 291-304.

Oliver, R. L. (1997). Satisfaction: A Behavioral Perspective on The Consumer (first edition). New York: McGraw-Hill Companies.

Pawitra, T.A., \& Tan, K.C. (2003). Tourist satisfaction in Singapore - a perspective from Indonesian tourists. Managing Service QualityAn International Journal, 13(5), 399 - 411. https://doi. org/10.1108/09604520310495868. 
Peña, A. I. P., Jamilena, D. M. F., \& Molina, M. Á. R. (2012). The perceived value of the rural tourism stay and its effect on rural tourist behavior. Journal of Sustainable Tourism, 20(8), 1045-1065. https://doi:10.1080/ 09669582.2012.667108

Prayag, G., Hosany, S., \& Odeh, K., (2013). The Role of Tourists' Emotional Experiences and Satisfaction in Understanding Behavioral Intentions. Journal of Destination Marketing and Management, 2(2). 11827. https://doi.org/10.1016/j.jdmm.2013.05.001.

Raj, A. (2007). The New Age of Tourism and the New Tourist. Institute of Tourism and Hotel Management, Bundelkhand University. Recuperado el 17/12/2018 en: http://www.indianmba.com/Faculty_ Column/FC565/fc565.html.

Rasoolimanesh, S. M., Dahalan, N., \& Jaafar, M. (2016). Tourists' perceived value and satisfaction in a community-based homestay in the Lenggong Valley World Heritage Site. Journal of Hospitality and Tourism Management, 26, 72-81. https://doi.org/10.1016/j.jhtm.2016.01.005.

Sánchez-Fernández, R., \& Iniesta-Bonillo, M. A. (2007). The concept of perceived value: A systematic review of the research. Marketing Theory, 7(4), 427-451. https://doi.org/10.1177/1470593107083165.

Sheham, L., Vargas-Sánchez, A., Presenza, A., \& Abbate, T. (2016). The use of intelligence in tourism destination management: an emerging role for DMOs. International Journal ofTourism Research, 18, 549-557. https://doi.org/10.1002/jtr.2072.

Si-Shyun, L. J. (2018). The moderating role of intercultural service encounters in the relationship among tourist's destination image, perceived value, and environmentally responsible behaviors. American Journal of Tourism Management, 7(1), 1-9. 1 https:// doi.org/10.5923/j.tourism.20180701.01.
Solís-Radilla, M., Hernández-Lobato, L. y Villagómez-Méndez, J. (2016). El valor percibido del destino turístico en relación con el perfil del turista en Acapulco, Guerrero-México. Investigación Administrativa 46(118), 1-28.

Sun, X., Chi, C. G. Q., \& Xu, H. (2013). Developing destination loyalty: The case of Hainan Island. Annals of Tourism Research, 4, 547-577. https://doi. org/10.1016/j.annals.2013.04.006.

Tanti, H., \& Raya, A. (2016). Responsible environmental behavior intention of travelers on ecotourism sites.Tourism and Hospitality Management, 22(2),135-150. 6 https://doi.org/10.20867/thm.22.2.4.

Thapa, B., \& Lee, J. (2017). Visitor experience in Kafue National Park, Zambia. Journal Ecotour., 16(2), 11213o. https://doi.org/10.1080/14724049.2016.1245737.

Wolf, I. D., Ainsworth, G. B., \& Crowley, J. (2017). Transformative travel as a sustainable market niche for protected areas: a new development, marketing and conservation model. Journal of Sustainable Tourism, 25(11), 1650-1673. https://doi.org/10.1080/o 9669582.2017.1302454.

Yánez, M. P. (2016). Las áreas naturales protegidas del ecuador: características y problemática general. Qualitas. 11, 41-55.

Zeithaml, V. A. (1988). Consumer perceptions of price, quality, and value: A means-end model and synthesis of evidence. Journal of Marketing, 52(3), 2-22. http://dx.doi.org/10.2307/1251446.

Zhang, C. B., Li, Y. N., Wu, B., \& Li, D. J. (2017. How WeChat can retain users: Roles of network externalities, social interaction ties, and perceived values in building continuance intention. Computers in Human Behavior, 69, 284, 293. https://doi. org/10.1016/j.chb.2016.11.069. 